acting head of the Department, and later head of the Department at the Royal Aircraft Establishment until May 1939

During 1921-31, he was an official momber of the Elasticity and Fatigue Sub-Committee of the Aeronautical Research Council and then official member of the Engine Sub-Committeø, Aeronautical Research Council, until 1939. His connexion with the Council continued until his retirement in 1960. Indeed, in his later years he used the Committee as his main vehicle of communication with the technical world; he published little elsewhere, largely because of the relevance of his work to defence projects.

He was a founder member of the Gas Turbine Collaboration Committee.

On June 1, 1939, Dr. Griffith took up the position of research engineer of Rolls-Royce, Ltd., at Derby, working on the initiation and prosecution of aero engino research, responsible to Mr. E. W. Hives, general manager (later Lord Hives, chairman). He was given a pleasant room at Duffield Bank House, a quiet haven on the banks of the Derwent, five miles from Derby.

Griffith's first work, eompleted in 1941, was an axial flow jot engine including twenty contra-rotating compressor stages, each driven independently by turbine blades at the tips of the compressor blades, ducted fan propulsion, centrifugal fuel supply and other items that were far in advance of contemporary practice. The highpressure part of the system was, in fact, built and tested. Throughout his work on jet propulsion, Dr. Griffith believed in the superior efficiency of the axial type compressor, and the contra-flow engine was followed by a series of design investigations of axial types, parallel with work on many component rig test investigations of com. bustion, blade form and rotor design.

A tochnical memorandum prepared by Dr. Griffith in 1945, together with a preliminary design scheme created under his supervision, were the basis of the Rolls-Royce Avon engine; this was followed in 1946 by his proposals for a by-pass engine. Preliminary design schemes for the latter type were completed early in 1947 and led to the Rolls-Royce Conway engine.

Early in 1941, Dr. Griffith realized that the thrust potential of a turbine ongine, combined with its low weight, provided a basis for the design of an aircraft which could take off and land vertically by virtue of engine thrust alone and thus only need sufficient wing area for its cruise condition. He made a detailed investigation of engine weight relative to size and showed that the 'Square-Cube' law, by which an engine's weight decreases as the cube of its linear dimensions, whereas the thrust only decreases as the square, would hold good down to quite small unit sizes. This convinced him of the advisability of using a number of small engines in order to obtain the optimum lift/weight ratio for vertical take-off applications. His first design studies of vertical take-off aircraft incorporated a multiplicity of small engines with means for deflecting their thrust downwards for taking-off and landing; control of the aircraft in the jet-borne phase being by variation of the thrust of engines situated fore and aft for pitch and separated laterally for roll. The possibility, with this scheme, of difficulty due to insufficiently rapid thrustresponse rate led Dr. Griffith to the idea of using compressed-air jets fed from engine compressor air bleed.

He conceived the scheme for testing this system, now well known as the 'Flying Bedstead', and supervised the preliminary design scheme, which incorporated two RollsRoyee Nene turbine engines arranged back to back with their thrust deflected downwards in a central position. Control air was tapped from the engine compressors and fed to control nozzles positioned fore and aft and on outriggers laterally. On August 3, 1954, this jet-lift test rig achieved its first free flight for 81 min. Many sub. sequent flights clearly demonstrated the success of Dr. Griffith's vertical take-off proposals. Parallel with these tests and until his retirement in 1960, Dr. Griffith initiated many aircraft design studies using specially designed lightweight lift engines and separate engines for forward thrust. Late in 1953 he commeneed a detailed investigation of a supersonic jet-lift transport designed for a Mach No. of $2 \cdot 6$ at 60,000 -ft. altitude.

Dr. Griffith's work was recognized by fellowship of the Royal Society in 1941, a C.B.E. in 1948, the award of the Silver Medal of the Royal Aeronautical Society in 1955 and, in 1962, the Bleriot Medal.

Although Dr. Griffith was very little known to most people within Rolls-Royce, due partly to the secluded location of his office, I was privileged to be his personal assistant and designer for twenty-one years, sharing his office for sixteen years at Duffield Bank House and later having an adjoining design office at Littloover Old Hall for the five years prior to his retirement.

Alan Arnold Griffith was truly a man of vision, quiet and retiring, resisting publicity yet fascinating to know intimately by daily contact. His brain provided new lines of thought for development in a continuous flow and our discussions were often enlivened by his ready wit and good humour.

DONALD Eyre

\section{Prof. E. P. Sharpey-Schafer}

Edward Peter Sharpey-Schafer, professor of medicine in the University of London at St. Thomas's Hospital Medical School, died on October 23 at the age of fifty-five.

His father was killed in the First World War and consequently he was brought up in the house of his famous grandfather, Sir Edward Sharpey-Schafer. He went to school at Winchester and entered King's College, Cambridge, as an exhibitioner and Kitchener Scholar. His clinical studies were completed at University College Hospital, where he obtained the Fellowes Gold and Silver Medals. After qualifying, he held the post of house physician to Sir Thomas Lewis, a position which he spoke of with great pride in later years. After serving as resident medical officer at the National Heart Hospital, he joined Sir Francis Fraser as first assistant in the Department of Medicine in the early days of the Postgraduate Medical School. He was appointed professor of medicine at St. Thomas's Hospital Medical School in 1948.

It is impossible to assess the enormity of the loss which St. Thomas's Hospital has suffered in the death of Prof. Sharpey-Schafer. He is the third member of their consultant staff to die in recent months, and though they were all men of high intellect and profound wisdom, he was undoubtedly the greatest of the three. Only those who were close to him had the opportunity to know him. He was essentially a shy man, which led people to think his manner brusque and off-hand, but his great human qualities showed themselves when he considered that someone was being treated unjustly. The same consideration for others was manifest in his investigations on patients : if ever it became apparent that one was suffering discomfort he immediately abandoned the procedure.

Prof. Sharpey-Schafer was an outstanding research worker, who is known throughout the world for his work on the circulation. However, he entered the field of original work in endocrinology and made important contributions in investigations of the thyroid, acromegaly and ovarian function. Although he forsook this sphere during the War, he still taught the younger endocrinologist some fundamental facts years later.

With Prof. J. McMichael he introduced cardiac catheterization as a method of examination of the cardiovascular system. From then onwards he continued to be fascinated by the control mechanisms in this system in health and disease. Every week he continued to make simple but fundamental observations on his patients, and a steady stream of original work flowed from his pen. He investigated hæmorrhage and heart-failure and remarked on the aspects of similarity in these two conditions. One of his 
particular achievements was the demonstration of vasodilatation in fainting subjects and the part played by complete immobility when soldiers fainted on parade. $\mathrm{He}$ demonstrated the vascular reflex abnormalitios in patients with tabes dorsalis, diabetes and barbiturate intoxication. This led to the simple treatment of the latter group of patients by blood volume expansion when they lapsed into a hypotensive state. Of recent years his dominant interest has been in the control of venous tone, and this led him on to the vascular changes during exercise. For months on end he would talk to all and sundry about this problem until he found at least a partial answer in the realm of ehemistry. This was rather unfamiliar territory to him and he soon enlisted the assistance of one of his staff in a series of conclusive investigations.

When Prof. Sharpey-Schafer first arrived at St. Thomas's Hospital he and his staff were thought of as experimentalists. $\mathrm{He}$ had an uphill task in earning the esteem and respect of the clinically orientated members of the nursing and medical staff. As the years passed he became more and more valued for his judgement both of individuals and of problems. Of the many people who sought his help and advice, not one was let down. The references he wrote for the junior members of the hospital staff sparkled with wit and impressed themselves on the reader by their originality. No idle clichés were ever found in these or any other of his writings.

Perhaps one of the most striking aspects of the personality of Prof. Sharpey-Schafer was his attitude to orthodoxy. He declared that he had an abhorrence for the whole of the pharmacopcia, and on one occasion to stress the point he crossed off all the drugs on his patients' treatment cards. He delighted in poking fun at the Establishment and in Who's Who stated that his recreation was "childish pursuits". In fact, he was a keen and accomplished naturalist and photographer, and when he produced a new batch of his colour photographs of birds or insects he was armed also with all the fascinating details of their life-habits, such as the speed of their wing beats, time and place of emergence, etc.

Those who knew "Sharpey" well appreciated the warmth of his character, his unfailing loyalty and the high standards which he demanded of everyone engaged in research. He was a man who always kept to his word and who could be relied on to help anyone who was in need. He will be an inspiration to all those who worked with him, but few will reach the standards which he achieved.

Prof. Sharpey-Schafer leaves a son and daughter by his first marriage. He married Dr. Sheila Howarth and they had two daughters.

IVOR H. MILLS

\section{NEWS and VIEWS}

School of Science: Massachusetts Institute of Technology

Dr. Jerome B. Wiesner has been appointed Dean of the School of Science in the Massachusetts Institute of Technology. Dr. Wiesner, now special assistant for science and technology and director of the U.S. Office of Science and Technology, will succeed Dr. George R. Harrison, who will retire at the end of this year.

\section{Dr. G. R. Harrison}

Dr. Harrison graduated from Stanford University and received his Ph.D. degree there in 1922 while an instructor in physics. After two years as a National Research Fellow at Harvard University he returned to the Stanford faculty and remained there until his appointment at the Massachusetts Institute of Technology in 1930. He was director of the Research Laboratory of Experimental Physics for twelve years before becoming dean of the School of Science in 1942. In spectroscopy, his field of specialization, Dr. Harrison invented several instruments of great value and compiled the M.I.T. Wavelength Tables, an encyclopædic work used by spectroscopists throughout the world. $\mathrm{He}$ was editor of the Journal of the Optical Society of America, co-author of Practical Spectroscopy and author of Atoms In Action, What Man May Be, and other books. During the Second World War, Dr. Harrison was chairman of the Instruments Section, and later chief of the Optics Division of the National Defense Research Committee, Office of Scientific Research and Development, and, for a time, chief of the Research Division at General MacArthur's headquarters in the south-west Pacific. He received the War Department Medal of Freedom and Presidential Medal for Merit. $\mathrm{He}$ was awarded the Rumford Medal of the American Academy of Arts and Sciences, the Frederic Ives Medal of the Optical Society of America, the Elliott Cresson Medal of the Franklin Institute and the Medal of the Society of Applied Spectroscopy.

\section{Dr. J. B. Wiesner}

Dr. Wiesner received bachelor of science, master of science and doctor of philosophy degrees from the University of Michigan. In 1940 he was appointed chief engineer of the Acoustical and Record Laboratory of the Library of Congress and in 1942 went to the Radiation Laboratory at Massachusetts Institute of Technology, where he was a member of the Microwave Components Division and then group leader of 'Project Cadillac', assigned to devise an airborne radar system. After the War, Dr. Wiesner spent a year at Los Alamos, returning to the Institute as assistant professor of electrical engineering. He was made an associate professor in 1947, professor in 1950 and Institute professor in 1962. In 1947 he became assistant director of the Research Laboratory of Electronies; in 1949, associate director, and in 1952, director. $\mathrm{He}$ was appointed acting head of the Department of Electrical Engineering in 1959. Dr. Wiesner's scientific contributions, particularly in the field of microwave theory, have been notable. He was chairman of the Institute's steering committee for a Center for Communication Sciences established in 1958. Dr. Wiesner was staff director of the American delegation to the Geneva Conference for the Prevention of a Surprise Attack in 1958, and for a number of years he has devoted much effort to the search for methods of arms control. Already a member of the President's Science Advisory Committee, he went on leave from the Institute in 1960 to become special assistant for science and technology to President Kennedy. $\mathrm{He}$ was also made director of the Office of Science and Technology when that agency was established in 1962. He has received the President's Certificate of Merit and is a member of the National Academy of Sciences.

\section{"Isotopes" : the Fiftieth Anniversary}

ON December 4 the Chemical Society (president, Prof. J. Monteath Robertson) will meet in the Department of Chemistry, University of Glasgow, to commemorate Fredorick Soddy's communication in Nature of exactly fifty years ago $(92,399$; December 4,1913$)$. Soddy was then working in the Physical Chemistry Laboratory of the University of Glasgow. This was a time of intense research and rapid advance in all fields of radioactivity. Although priority issues are inevitably debatable, it remains evident that the University of Glasgow made an 